Article

\title{
Antecedents of the Green Behavioral Intentions of Hotel Guests: A Developing Country Perspective
}

\author{
Farida Saleem (D)
}

check for

updates

Citation: Saleem, F. Antecedents of the Green Behavioral Intentions of Hotel Guests: A Developing Country Perspective. Sustainability 2021, 13, 4427. https://doi.org/10.3390/ su13084427

Academic Editor: Gomaa Agag

Received: 13 March 2021

Accepted: 14 April 2021

Published: 15 April 2021

Publisher's Note: MDPI stays neutral with regard to jurisdictional claims in published maps and institutional affiliations.

Copyright: (c) 2021 by the author Licensee MDPI, Basel, Switzerland. This article is an open access article distributed under the terms and conditions of the Creative Commons Attribution (CC BY) license (https:// creativecommons.org/licenses/by/ $4.0 /)$.
Department of Management, College of Business Administration, Prince Sultan University, Riyadh 11586, Saudi Arabia; fsaleem@psu.edu.sa

\begin{abstract}
The current study sought to extend the literature on antecedents of the green behavioral intentions of hotel guests in a developing country context. Building on the theory of planned behavior and moral norm-activation theory, antecedents of the green behavioral intentions of hotel guests were proposed and tested using a developing country as a field of study. Data were collected from 203 hotel guests, and the proposed model was analyzed using a structural equation modeling technique. The results showed that altruism helps in developing positive attitudes, and these attitudes have a significant influence on hotel guests' green behavioral intentions. Similarly, cognitive aspects, including quality attributes and value for money, also play a role in developing positive intentions for willingness to pay more and revisit intentions. Inconvenience has a significant negative impact on revisit intentions, and quality attributes have a significant positive impact on willingness to pay more.
\end{abstract}

Keywords: collectivism; altruism; attitudes; cognitive aspects; behavioral intentions

\section{Introduction}

Green purchase behavior is purchasing and consuming a product that presents no harm to the environment [1]. The focus of this behavioral outcome is to benefit the whole society. The importance given by the customer to environmental issues has made business organizations follow proenvironmental strategies [2]. Concern for the environment has increased over the last few decades [1,3]. The improved awareness level of consumers has made environmentalism a significant issue in the marketplace. Ecologically conscious customers are looking for green products and services and prefer firms that have integrated environmental concerns in their strategies [2]. The number of customers who think that they are going to make more proenvironmental decisions is increasing every year [4]. Following environmental initiatives such as the International Hotels Environment Initiative (IUEI) in 1993 and the emergence of green consumerism and environmental movements, which has spurred criticism of tourism and hotel practices, the hotel industry is making efforts to attain ecological sustainability by reducing the consumption of water, energy, and raw materials [5].

The eco-friendly or sustainable hotels phenomenon is not a fad with a short life. These types of hotels have existed for more than three decades, and their numbers have continued to multiply [6]. According to Pizam, "As to the question of whether green hotels will be a fact of life in the middle- and long-term future of the hotel industry, it is my personal belief that with the spiraling costs of energy and the accelerated depletion of the planet's resources, hotels, like most other businesses, will have no other choice but to become "real green" [6]. As the growing number of hotel industry customers are becoming aware of the environmental activities of the hotels they choose to stay in, many hotels are now integrating their strategies with the principles of sustainable development $[7,8]$.

Increased awareness about the impact of hotels on the environment and the environmental policies that hotels follow to reduce their impact has a significant impact on customers' hotel selection. Even though there is much research about hotel attributes and 
how these attributes affect the hotel selection process, minimal research has analyzed the environmental attributes by hotels [9].

To date, customers and green behavioral intentions, as well as its antecedents, have dominated the marketing literature. The conclusions are both operational and conceptual. These studies have successfully identified the relationships among and between particular variables (that can develop favorable intentions) and have helped us to better understand and enabled us to better discriminate between these constructs. Merli et al. [8], focusing on hospitality industry customers, found a positive association between the ecolabeling of hotels and hotel guests' satisfaction and their loyalty toward green hotels. There is no doubt due to the implicit assumption that the green behavioral intentions of customers lead directly to favorable outcomes for hotel management [10,11]. However, according to González-Rodríguez et al. [12], there is a "limited understanding of customers' environmental concern, as variable to understand the importance ascribed to environmental practices by consumers".

Many studies in the hospitality literature focused on the impact of green practices by hotels on hotel guests' satisfaction and their loyalty $[8,10,13]$. As there is no straightforward relationship between intentions and actual behavior [14], personal characteristics, including values and beliefs, and evaluations of customers' quality attributes can be influential. Sukawati et al. [15], using interview data from Indonesia, also concluded that values and beliefs do not automatically translate into actual behavior; rather, they are only two of the many factors influencing responsible behavior. However, researchers have overlooked the altruistic and collectivistic orientation of hotel guests while showing their hotel revisit intentions or their willingness to pay more. Another factor that has also been neglected in the hospitality literature is the understanding of the process of how guests make proenvironmental behavioral intentions.

What are the antecedents of the green behavioral intentions of hotel guests in an emerging market? This question still needs to be answered. It has also been observed that less attention has been directed toward examining corporate social responsibility (CSR) generally and environmentalism particularly in emerging and pre-emerging market contexts [16]. Pakistan, a developing market, presents a different country-level context. The attitude and behavior of customers toward the environmental activities of firms including hotels are very different from that of customers from developed economies $[17,18]$. Hence, in order to better understand factors affecting the proenvironmental behavior of hotel guests, a comprehensive model using the moral norm-activation theory by Schwartz [19] and the theory of planned behavior [20] was proposed and analyzed.

The contributions of the current study are two-fold. First, we propose a holistic model of the antecedents of green behavioral intentions, considering moral norm-activation and the theory of planned behavior. Second, we test the model in the hospitality industry context, using a developing country as a field of study for a better understanding of the behavior of customers there. It is especially relevant for environmentalism to distinguish the research context of developing and developed countries. The proenvironmental behavioral intentions of hotel guests can be affected by social, economic, and cultural conditions [15]. Developing economies do not share the same cultural and social values, norms, economic conditions, and priorities that can be aligned with corporate social and environmental behavior as in "Western" nations [21,22]. Presenting and testing a holistic model of determinants of the green behavioral intentions of customers in an emerging economic perspective will not only help in providing theoretical implications by generalizing the concepts that have largely been developed through the literature coming from Western and developed economies but will also provide practical and managerial implications by the identification of the determinants of the green behavioral intentions of customers in an emerging market. 


\section{Environmental Impact of Hotels}

The specific operating characteristics of hotels have made them highly resource dependent. This industry consumes large amounts of water, energy, nondurable products, and raw materials. Thus, the environmental impact of these facilities is far more significant than other types of commercial buildings of a similar size, except hospitals [23,24]. Unnecessary and excessive consumption of water, energy, and nondurable products is estimated to account for $75 \%$ of environmental impacts created by this industry, followed by emissions released to air, water, and soil [12,23]. Similarly, many hotels that attract tourists are located in very delicate natural environments [12,25].

Depending on the process used for generating electricity, cooling, and heating systems, a typical hotel emits between 160 and $120 \mathrm{~kg}$ of $\mathrm{CO}_{2}$ per square meter of the room floor annually [3]. According to Bohdanowicz [26], European hotels released more than ten megatons of carbon dioxide. Similarly, a typical hotel produces more than $1 \mathrm{~kg}$ of waste per guest per day, resulting in excessive tons of waste every month. The American lodging industry consumes about 55.6 TWh of energy per year; however, their counterparts in Europe use about 39 TWh.

After this introduction of the study, Section 2 focuses on the theoretical background and hypotheses development while synthesizing the literature available in the research area. Section 3 outlines the methodology, including the data collection procedure, measures, and sample profile, followed by Section 4 , which regards the methods adopted for data analysis and the results of the study. Discussion, implications, limitations, and conclusions are presented in Section 5 .

\section{Literature Review}

\subsection{Behavioral Intentions of Green Hotel Consumers}

Many hospitality and marketing researchers have reached a consensus on the fact that the long-term success of a company is dependent on positive pre- or postpurchase decisions, e.g., $[13,27-29]$. Hence, several studies have tried to explore the complex decision-making process involved in developing favorable behavioral intentions (including the willingness to pay more and revisit intentions) [10]. The comprehension of this process can indicate decision formation [10,30,31].

The theory of planned behavior (TPB) [20] has been used by many researchers in the sustainability literature to study green behavior, e.g., [10,28,32,33], either by combining it with another theoretical model or by proposing extension in this theory. Despite the general usefulness of the TPB, several studies made efforts to improve this theory's explanatory power by adding additional constructs within the TPB model [34]. For example, Han and Kim [28] extended the model by including the relationship between service quality and customer satisfaction, overall image, and frequency of past behavior as predictors of behavioral intentions. Kim and Han [9] included environmental concerns, customer effectiveness, and environmentally conscious purchase behavior relationships in the model. Similarly, Chen and Tung [33] built an extended TPB research model incorporating moral norms and the consequences of recycling to explain consumers' recycling intentions.

The performance of a specific behavior can be explained with the help of positive intentions to perform that behavior [20]. The actual behavior can be effectively explained with the help of positive behavioral intentions. As behavioral intentions are the willingness or probability to perform a specific behavior, the theoretical foundations of the TPB have successfully been used by many researchers in explaining environmentally conscious purchase decisions [31,35].

Researchers in the hospitality context $[28,35,36]$ have used revisit intentions to predict environmentally friendly hotel customers' behavioral intentions. Similarly, Kim and Han [10] used willingness to pay as a behavioral intention of environmentally friendly hotel customers. Han, Hus, and Lee [37] and Han et al. [36] used revisit intentions, word of mouth intentions, and willingness to pay more as behavioral intentions of such customers. 
For the current study, to predict environmentally friendly intentions, revisit intentions and customer willingness to pay more to stay at environmentally friendly hotels are used.

\subsubsection{Collectivism and Behavioral Intentions}

Collectivist orientation makes people more dependent on the group they belong to; they are less self-reliant and usually do not exercise freedom of choice [38-40]. Whereas individualistically oriented people are independent, they have less focus on group harmony, feel competition from people around them, and try to exercise freedom of choice [38,39]. Individualism or collectivism orientation has attracted researchers' attention and has been investigated at both the individual level (orientation of individuals within a culture) and aggregate level (difference across cultural levels) [40,41].

Collectivist orientation can motivate individuals to perform certain behaviors at individual levels [40,41]. This value orientation has been found to influence a range of social behaviors, including ethical decision making [42]. People with collectivist orientations are more likely to be involved in proenvironmental behaviors than people with individualistic tendencies [43]. According to Wang et al. [44], the collective values of individuals are a significant predictor of their intentions toward green purchases. Similarly, Laroche et al. [45] suggested that collectivist-oriented people are friendlier toward the natural environment. Kim and Choi [40] also found collectivism has an impact on green purchase behavior. The positive and significant impact of collectivism on proenvironmental behavior has been supported by many investigations, i.e., [44,46-48]. Goh and Wahid [47] studied Malaysian consumer behavior and found collectivism as an essential determinant of green purchases. Kirmani and Khan [48] found collectivism as a predictor of environmental concern in Indian consumers. Similarly, Wang et al. [44] found collectivism as a predictor of green purchase attitude and green purchase intentions in Chinese hotel consumers.

The impact of values on individuals' attitudes and behavior has been theoretically and empirically supported $[49,50]$. Individuals process only the information congruent with their value orientation [51]; hence, a person with an individualistic orientation will be more concerned about themselves rather than their impact on the environment. Based on the above findings, the following hypotheses are made.

Hypothesis 1a (H1a). Customers with a collectivist orientation will give importance to environmental issues and (b) feel convenient to locate an environmentally friendly hotel.

\subsubsection{Altruism and Behavioral Intentions}

The moral norm-activation theory by Schwartz [19] proposes that the probability of performing particular behavior depends on the awareness of the consequences of a particular behavior. According to the moral norm-activation theory, the occurrence of altruistic behaviors is dependent on an individual's moral norms that are prompted due to their understanding of the negative outcomes of a specific behavior or the belief that their actions can reduce or limit these negative outcomes. As the tradeoff between the individual and collective benefit is the basis of proenvironmental behavior, many researchers, e.g., $[41,52,53]$, in their investigations have intellectualized altruism within the framework of the Schwartz moral norm model [19] and, by using different environmental behaviors, have provided substantial support of this theory.

Despite limited empirical investigations, altruistic values have shown a significant impact on environmental attitudes and behaviors [25]. Mas'od and Chin [54], using a sample of green hotel consumers from Malaysia, found that altruism positively influences the consumer green hotel selection. Teng et al. [55], using the theory of planned behavior in China and Taiwan, found that consumers' perception of behavioral control for green hotel selection is affected by their altruistic values. Han et al. [56], investigating 263 guests at green hotels in Vietnam, found the important role of individual proenvironmental values and the norms of hotel guests and their engagement in environmentally friendly behavioral intentions. Similarly, Wang et al. [25] empirically supported that altruistic values 
impact green purchase behavior and green purchase intentions in Chinese hotel consumers. Individuals with high altruistic values paid more attention to the negative consequences of environmental issues and their impact on humans [41] and had proenvironmental attitudes. Hence, the following hypotheses are proposed:

Hypothesis 2a (H2a). Customers with a high degree of altruism will give importance to environmental issues and (b) feel it convenient to locate an environmentally friendly hotel.

\subsubsection{Attitudes and Behavioral Intentions}

Positive attitudes are linked with positive purchase intentions [57]. Many investigations have to provide empirical support for the positive impact of green purchase attitudes and green purchase intentions, e.g., [25,57,58]. Wang et al. [25] found a positive impact of green purchase attitudes on green purchase intentions in Chinese consumers. Jaiswal and Kant [57] found the same results in Indian consumers, and similarly, Yoon and Kim [58], analyzing USA university students, found attitudes as the strongest predictor of green advertising intentions.

The two most studied and cited attitudes in the environmentalism literature are importance and inconvenience. Importance is how much importance one gives to environmentally friendly behaviors, while inconvenience is how much one feels it inconvenient to perform environmentally friendly behavior [59]. These are two different attitudes and can be present at the same time; for example, one might feel that it is imperative to behave in an environmentally friendly manner but might also feel the inconvenience of behaving in an environmentally friendly manner.

The majority of prior studies, e.g., [45,60-62], have used these two types of attitudes concerning the recycling behavior of environmentally friendly consumption and have identified that importance has a positive impact, while inconvenience has a negative impact on the environmentally friendly behavior of individuals. Following the lines of Laroche et al. [45], it is believed that no matter how much importance one gives to environmentally friendly activities, the perception about the inconvenience to perform such activities can also have an impact on the intentions to perform environmentally friendly behaviors. Hence, the following hypotheses are proposed.

Hypothesis 3a (H3a). Importance given to environmental issues will positively impact the willingness to pay higher prices to stay at an environmentally friendly hotel and (b) the revisit intentions of customers.

Hypothesis 3c (H3c). Inconvenience faced to locate an environmentally friendly hotel will have a negative impact on the willingness to pay higher prices to stay at an environmentally friendly hotel and $(d)$ on the revisit intentions of customers.

\subsubsection{Cognitive Aspects and Behavioral Intentions}

According to Lee et al., "cognitive image relates to consumers' belief about an object (such as a green hotel) based on an evaluation of its known attributes" [63]. Positive cognitive aspects regarding an environmentally friendly hotel or the green claim strength of an environmentally friendly hotel have been reported to have two significant dimensions, i.e., value for money and quality attributes [63]. Perception of service quality and value for money are taken as cognitive aspects that might impact consumers' behavioral intentions.

Previous studies $[45,64]$ have adopted a cognitive approach while focusing on perception and expectations about service quality to study the behavioral intentions of consumers. The perception of high quality has a positive impact on intended behavior. Baker and Crompton [65] identified that perceived quality has more substantial total effects on behavioral intentions than satisfaction. Similarly, green products' perceived quality has implications for green purchase intentions [66]. Prior literature [67,68] has also identified product quality as an antecedent of green purchase intentions and behavior. Similarly, 
according to Cronin et al. [69], in quick-service restaurants, satisfaction due to quality attributes is very critical in the repurchase decisions from the same vendors.

Perceived value for money is a difficult concept to define and measure. According to McDougall and Levesque [70], it can be defined as "perceived value is the results or benefits customers receive in relation to total costs (which include the price paid plus other costs associated with the purchase)." Primarily it is the difference between cost paid and benefits received. The satisfaction level of customers who perceive that they receive value for money is higher than those who do not perceive to receive value for money.

The relationship between perceived value for money and customer intended behavior has been part of much service marketing literature [70,71]. Park and Njite [71] proposed that perceived value for money impacts the satisfaction and future behavioral intentions of customers. Regarding behavioral intentions, perceived value for money is a critical aspect [70,71]. Ritter et al. [68] found that both value for money and quality attributes influence green product purchases while studying Brazilian customers. Similarly, Lee et al. [63] also suggested that cognitive components, including value for money and quality attributes, can impact the behavioral intentions of environmentally friendly hotel customers. Hence, for studying environmentally friendly hotel customers' intended behavior, it is believed that this intended behavior is affected by the customers' perception of the value for money and quality attributes.

Hypothesis 4a (H4a). The higher the perceived value for money, the higher the willingness to pay more and the (b) revisit intentions of customers.

Hypothesis $4 \mathbf{c}(\mathbf{H} 4 \mathbf{c})$. The more positive the perception about quality attributes, the higher the willingness to pay more and the (d) revisit intentions of customers.

The model of the green behavioral intentions of hotel guests based on the purposed hypotheses is presented in Figure 1.

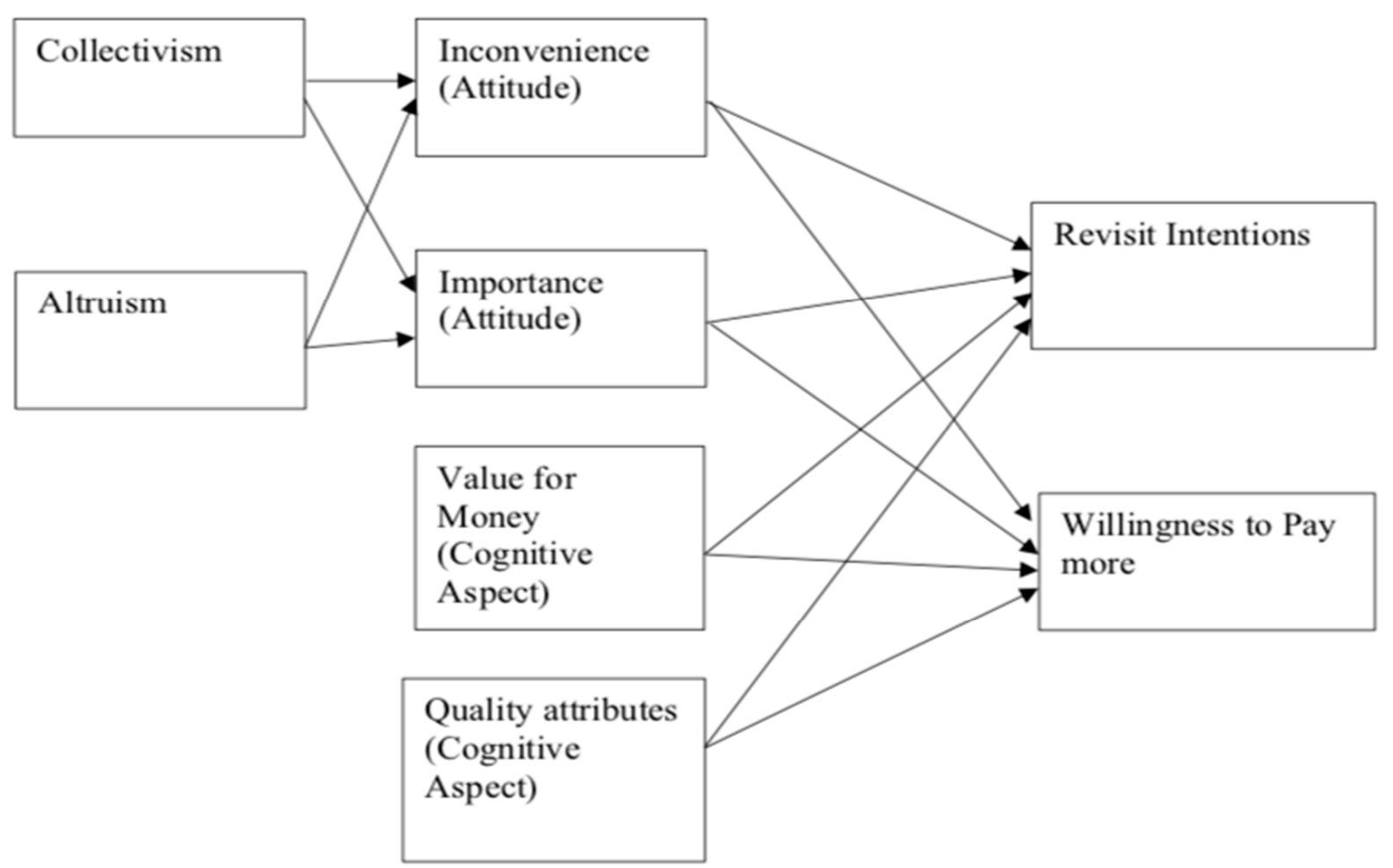

Figure 1. Proposed framework of the green behavioral intentions of hotel guests. 


\section{Methodology}

\subsection{Data Collection}

Data were collected from the guests of hotels located in Rawalpindi and Islamabad, Pakistan. A survey was developed on Google Forms, and a cover letter describing the aim of the study and URL address for the online survey form were placed in hotel receptions and rooms. A total of 203 usable responses from hotel guests were received over a period of 5 weeks and were used for data analysis.

\subsection{Measures}

Each latent construct was measured using multiple items, all adapted from previous literature. The multi-item constructs in the questionnaire were altruism, collectivism, inconvenience, importance, value for money, quality attributes, willingness to pay more, revisit intentions, marketing strategy, and operational strategy. Guagnano's [53] 7-item scale using a five-point Likert scale, where (1) "strongly disagree" and (5) "strongly agree," was used for the measurement of altruism. For measuring collectivism, a three-item scale was adopted from Yamaguchi [72] and was measured on a five-point scale from (1) "not at all important" to (5) "extremely important." Inconvenience and importance, measures for attitude, were measured with the help of three items each on a five-point Likert scale adopted from Laroche et al. [59]. Value for money and quality attributes were measured with the help of three and eight questions, respectively, adopted from Lee, Hus, and Kim [63]. Willingness to pay more and revisit intentions were measured with the help of 5 and 3 items, respectively, adopted from Han, Hus, and Lee [37]. All scales mentioned otherwise were measured using five points, ranging from strongly agree to strongly disagree.

\subsection{Sample Profile}

Among the respondents in the final sample of 203 responses, $61 \%$ were male, and 39\% were female; $73 \%$ of them were employed, and $27 \%$ had their own business or were unemployed; $14 \%$ of the respondents had a Bachelor's degree, $67 \%$ held a Master's, degree and $18 \%$ had other degrees or higher qualification; and $69 \%$ respondents were staying at 5 -star hotels, $23 \%$ were staying at 3-star hotels, while $8 \%$ were from 3 -star hotels.

\section{Data Analysis}

An incremental or two-step approach to the structural equation modeling technique (SEM) was used for data analysis. Data were analyzed using both SPSS 16 and AMOS 16.

\subsection{Reliability}

Cronbach's Alpha scores and composite reliability index were used to check the internal consistency and reliability of factors. Cronbach's Alpha score ranged between 0.75 and 0.91 for each variable present in the model, while it was 0.89 for the full scale. Similarly, the composite reliability for all variables present in the model lies between 0.76 and 0.91 . The results of the reliability analysis are given in Table 1.

\subsection{Validity}

According to the validity results, altruism 3 (ALT3) and value for money 2 (VM2), both observed variables, were unsuccessful in loading into their respective latent variables, with square multiple correlation values equal to 0.23 and -0.34 for ALT3 and VM3, respectively. However, the rest of the variables showed convergent validity by loading into their latent factors with acceptable squared multiple correlation values $(>0.5)$.

Discriminant validity was assessed with the help of the criterion mentioned by Fornell and Larcker [73], where average variance extracted (AVE) values were analyzed with reference to the square of the correlations of each latent variable. The results supported the discriminant validity of all constructs, as the AVE values for all variables were greater than the square of the correlations of each latent variable. The results are reported in Table 1. 
Table 1. Descriptive statistics, correlations, shared variance, composite reliability, and average variance extracted (AVE) values for constructs.

\begin{tabular}{|c|c|c|c|c|c|c|c|c|c|c|c|c|c|c|}
\hline & Variable & No. of Items & $\mathrm{CR}$ & Alpha & 1 & 2 & 3 & 4 & 5 & 6 & 7 & 8 & 9 & 10 \\
\hline 1 & $\mathrm{COL}$ & 3 & 0.90 & 0.90 & 0.75 & & & & & & & & & \\
\hline 2 & ALT & 6 & 0.85 & 0.85 & $\begin{array}{l}0.70 * \\
(0.49)\end{array}$ & 0.50 & & & & & & & & \\
\hline 3 & INC & 3 & 0.82 & 0.82 & $\begin{array}{c}-0.58 * \\
(0.33)\end{array}$ & $\begin{array}{c}-0.69 * \\
(0.47)\end{array}$ & 0.60 & & & & & & & \\
\hline 4 & IMP & 3 & 0.76 & 0.75 & $\begin{array}{l}0.65 * \\
(0.42)\end{array}$ & $\begin{array}{l}0.60 \text { * } \\
(0.36)\end{array}$ & $\begin{array}{c}-0.47^{*} \\
(0.22)\end{array}$ & 0.51 & & & & & & \\
\hline 5 & VM & 2 & 0.85 & 0.84 & $\begin{array}{l}0.26^{*} \\
(0.06)\end{array}$ & $\begin{array}{l}0.48^{*} \\
(0.23)\end{array}$ & $\begin{array}{c}-0.14^{* *} \\
(0.01)\end{array}$ & $\begin{array}{l}0.37^{*} \\
(0.13)\end{array}$ & 0.73 & & & & & \\
\hline 6 & QA & 8 & 0.89 & 0.90 & $\begin{array}{l}0.56^{*} \\
(0.31)\end{array}$ & $\begin{array}{l}0.56^{*} \\
(0.31)\end{array}$ & $\begin{array}{c}-0.40 * \\
(0.16)\end{array}$ & $\begin{array}{l}0.39 * \\
(0.15)\end{array}$ & $\begin{array}{l}0.38 * \\
(0.14)\end{array}$ & 0.53 & & & & \\
\hline 7 & RVI & 3 & 0.87 & 0.87 & $\begin{array}{l}0.50^{*} \\
(0.25)\end{array}$ & $\begin{array}{l}0.35^{*} \\
(0.12)\end{array}$ & $\begin{array}{c}-0.30 \\
(0.09)\end{array}$ & $\begin{array}{l}0.50 * \\
(0.25)\end{array}$ & $\begin{array}{l}0.45^{*} \\
(0.20)\end{array}$ & $\begin{array}{l}0.54^{*} \\
(0.29)\end{array}$ & 0.70 & & & \\
\hline 8 & WPM & 5 & 0.90 & 0.89 & $\begin{array}{l}0.66^{*} \\
(0.43)\end{array}$ & $\begin{array}{l}0.55^{*} \\
(0.30)\end{array}$ & $\begin{array}{c}-0.45^{*} \\
(0.20)\end{array}$ & $\begin{array}{l}0.66^{*} \\
(0.43)\end{array}$ & $\begin{array}{l}0.49 * \\
(0.24)\end{array}$ & $\begin{array}{l}0.63 * \\
(0.39)\end{array}$ & $\begin{array}{l}0.58 \text { * } \\
(0.33)\end{array}$ & 0.63 & & \\
\hline
\end{tabular}

Shared variance in parenthesis; AVE in diagonal; ${ }^{*} p<0.01 ;{ }^{* *} p<0.05$; CR: composite reliability.

\section{Results}

\subsection{Model Estimation and Analytical Strategy}

A two-step approach to SEM was used as an analytical strategy. In the first step, the measurement model was analyzed, while in the second step, the structural model was analyzed using the maximum likelihood estimation (MLE) method.

\subsubsection{Measurement Model}

The measurement model results identified a good fitted model, where not only were all items loaded into their respective constructs but also had an acceptable $t$-value $(>2.50)$, factor loadings $(>0.5)$, and $\mathrm{R}^{2}(>0.5)$. Therefore, none of the observed variables were considered for removal from the model [74]. The results of the measurement model are given in Table 2 .

Table 2. Confirmatory Factor Analysis (CFA) of items present in the model.

\begin{tabular}{|c|c|c|c|c|}
\hline Construct/Variable & $\beta$ & Alpha & CR & AVE \\
\hline Collectivism & & 0.90 & 0.90 & 0.75 \\
\hline COL1 & 0.856 & & & \\
\hline COL2 & 0.926 & & & \\
\hline COL3 & 0.828 & & & \\
\hline Altruism & & 0.85 & 0.85 & 0.50 \\
\hline ALT1 & 0.715 & & & \\
\hline ALT2 & 0.721 & & & \\
\hline ALT4 & 0.720 & & & \\
\hline ALT5 & 0.743 & & & \\
\hline ALT6 & 0.578 & & & \\
\hline ALT7 & 0.665 & & & \\
\hline Inconvenience & & 0.82 & 0.82 & 0.60 \\
\hline INC1 & 0.812 & & & \\
\hline INC2 & 0.804 & & & \\
\hline INC3 & 0.710 & & & \\
\hline Importance & & 0.76 & 0.75 & 0.51 \\
\hline IMP1 & 0.754 & & & \\
\hline IMP2 & 0.711 & & & \\
\hline IMP3 & 0.676 & & & \\
\hline Value for Money & & 0.85 & 0.84 & 0.73 \\
\hline VM1 & 0.903 & & & \\
\hline VM3 & 0.815 & & & \\
\hline
\end{tabular}


Table 2. Cont.

\begin{tabular}{ccccc}
\hline Construct/Variable & $\beta$ & Alpha & CR & AVE \\
\hline Quality Attributes & & 0.89 & 0.90 & 0.53 \\
QA1 & 0.803 & & \\
QA2 & 0.736 & & \\
QA3 & 0.682 & & \\
QA4 & 0.728 & & \\
QA5 & 0.711 & & \\
QA6 & 0.756 & & \\
QA7 & 0.689 & 0.87 & \\
QA8 & 0.708 & & \\
Revisit Intentions & & & \\
RVI1 & 0.808 & 0.870 & \\
RVI2 & 0.842 & & & \\
RVI3 & 0.847 & & \\
WPM1 & & & \\
WPM2 & 0.831 & & \\
WPM3 & 0.809 & & \\
WPM4 & 0.805 & & \\
WPM5 & 0.760 & 0.750 & & \\
\hline
\end{tabular}

Goodness-of-fit indices: $\chi 2=694 ;$ d.f. $=466 ; \chi 2 /$ d.f. $=1.49 ; p<0.001 ;$ CFI $=0.94 ;$ GFI $=0.83 ;$ AGFI $=0.80$ $\mathrm{RMR}=0.04 ;$ RMSEA $=0.04 ; \beta$ : standardized coefficient; Alpha: Cronbach's alpha; CR: composite reliability; AVE: average variance extracted.

\subsubsection{Structural Equation Modeling}

The structural model was run by taking the items that were successfully loaded into their respective latent factor. The hypothesis related to collectivism and inconvenience was rejected, while the rest of the proposed hypotheses were accepted. The structural model results are presented in Table 3 and Figure 2. One path of collectivism was insignificant, while one path was significant; for altruism, both paths were significant. Hence, Hypothesis H1b was rejected, and Hypotheses 1a, 2a, and 2b were accepted. All paths leading to behavioral intentions were also significant; hence, Hypotheses $\mathrm{H} 3$ and $\mathrm{H} 4$ were also accepted.

Table 3. Structural model and path analysis.

\begin{tabular}{ccccc}
\hline Causal Path & Unstandardized Coefficient & $\boldsymbol{t}$-value & Hypotheses & Supported \\
\hline COL $\geq$ IMP & 0.308 & $4.33^{*}$ & Hypothesis $1 \mathrm{a}$ & Yes \\
COL $\geq$ INC & -0.090 & -0.813 & Hypothesis $1 \mathrm{~b}$ & No \\
ALT $\geq$ IMP & 0.249 & $3.62^{*}$ & Hypothesis $2 \mathrm{a}$ & Yes \\
ALT $\geq$ INC & -1.01 & $-7.88^{*}$ & Hypothesis $2 \mathrm{~b}$ & Yes \\
IMP $\geq$ WPM & 1.56 & $7.93^{*}$ & Hypothesis 3a & Yes \\
IMP $\geq$ RVI & 1.56 & $7.42^{*}$ & Hypothesis $3 \mathrm{~b}$ & Yes \\
INC $\geq$ WPM & -0.191 & $-2.35^{* * *}$ & Hypothesis $3 \mathrm{c}$ & Yes \\
INC $\geq$ RVI & -0.318 & $-3.36^{*}$ & Hypothesis $3 \mathrm{~d}$ & Yes \\
VM $\geq$ WPM & 0.181 & $3.06^{* *}$ & Hypothesis $4 \mathrm{a}$ & Yes \\
VM $\geq$ RVI & 0.226 & $2.95^{* *}$ & Hypothesis $4 \mathrm{~b}$ & Yes \\
QA $\geq$ WPM & 0.186 & $3.25^{* *}$ & Hypothesis $4 \mathrm{c}$ & Yes \\
QA $\geq$ RVI & 0.155 & $2.11^{* * *}$ & Hypothesis $4 \mathrm{~d}$ & Yes \\
\hline
\end{tabular}

Goodness-of-fit indices: $\chi^{2}=1029 ;$ d.f. $=480 ; \chi 2$ d.f. $=2.14 ; p<0.001 ; \mathrm{CFI}=0.87 ; \mathrm{GFI}=0.78 ;$ AGFI = 0.75; RMSEA $=0.07 ;{ }^{*} p<0.001,{ }^{* *} p<0.01,{ }^{* * *} p<0.05$. 


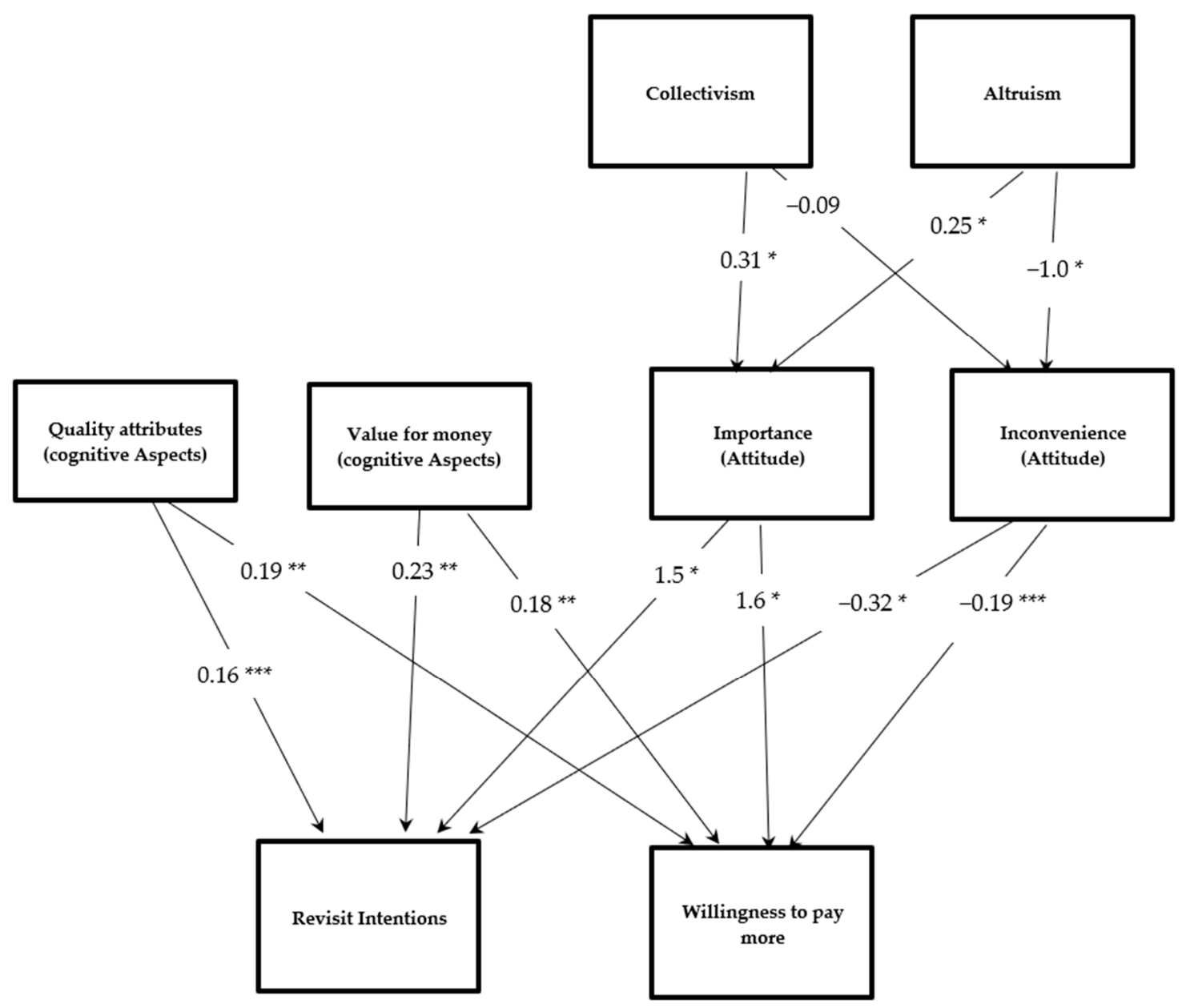

Figure 2. Antecedents of green behavioral intentions. ${ }^{*} p<0.01,{ }^{* *} p<0.05,{ }^{* * *} p<0.10$.

\section{Discussion}

The current study presented and tested a model for explaining the customer behavioral intention formation to stay at an environmentally friendly hotel. With the exception of collectivism, all the proposed hypotheses are accepted. This study provides theoretical and managerial implications for comprehending the determinants of hotel guests' intentions to visit a green hotel. The primary aim of this study was to discover the antecedents of the green behavioral intentions of hotel guests in an emerging economy. The study results identified a significant relationship between the behavioral intentions (including, revisit intentions and willingness to pay more) and hotel guests' environmentally friendly attitudes, their cognitive evaluations, and altruism. One of the managerial implications of these results is that organizations can use their customers' behavioral intentions to shape up their strategy or use these intentions as their differentiation strategy.

The first important finding is the impact of the importance on both willingness to pay more and revisit intentions. Out of four constructs (inconvenience, importance, value for money, and quality attributes), the importance customers give to environmentally friendly behavior has the most substantial impact on their intention development. This result is consistent with the findings of many authors [25,45,57,58]. Studies, e.g., [2,25], have suggested that environmentally friendly attitudes and concerns favor environmentally conscious businesses. The second important construct that influences behavioral intentions is quality and value for money for willingness to pay more and inconvenience and value for money for revisit intentions, respectively. The quality attributes directly influence willingness to pay more, while inconvenience more significantly negatively affects revisit intentions; however, value for money predicts both the revisit intentions and willingness to pay more 
This finding is consistent with Lee, Hus, Han, and Kim [63], Cheung and To [66], and Park and Njite [71], who identified that cognitive aspects play an essential role in future intention development. The study by Laroche et al. [59] revealed that a segment of consumers willing to pay extra for environmentally friendly products is large enough to warrant marketers attention. Similar conclusions were also advanced by many recent investigations.

The third important finding is related to the insignificant relationship between collectivism and inconvenience. These results are not consistent with the findings of many studies, e.g., [44,46-48]. The context of this study is also important and needs reflection at this stage. The social and cultural values have implications for shaping attitudes. Pakistan, being a collectivist society [38], has a sociocultural environment that is relationship oriented. Because Pakistani hotel guests were the sample of our study, the explanation of the results should be with reference to respondents' collectivist orientation. As the majority of respondents share a collectivist orientation, this factor becomes insignificant in explaining its impact on attitudes.

\section{Theoretical and Managerial Implications}

One of the theoretical implications of the current investigation is the validation of the moral norm-activation model by Schwartz [19] in a new social, cultural, and economic context. The results validate that altruistic beliefs have an impact on the behavioral intentions of individuals. Hence, we can conclude that people with high altruism take notice of their actions, which can result in negative consequences for the environment. In the end, it is suggested that the consumer's decision-making process for environmentally friendly purchase decisions is best modeled as a complex system that incorporates several factors that impact behavioral intentions. It is believed the evidence presented in this investigation supports this position. The second theoretical implication is related to the generalizability of the theory of planned behavior TPB [20] in the context of sustainability, the hospitality industry, and developing countries. The results indicated that proenvironmental attitudes, importance and inconvenience, are affected by the altruistic and collectivistic beliefs of customers and can translate into developing positive revisit intentions and their willingness to pay more.

As altruism can develop positive attitudes in hotel guests, managers from hotels can develop marketing campaigns about their proenvironmental initiatives while focusing on the altruistic orientation of their customers. This will help in not only creating environmental awareness in their customers but also positive attitudes. Secondly, as inconvenience in locating an environmentally friendly hotel also has an impact on the revisit intentions and guests' willingness to pay more, hotel managers should focus on minimizing the inconvenience that guests can face while locating their hotel. This would not only require the presence of hotels at different social media forums (Tripadvisor, Booking.com, etc.) from where usually customers make reservations but also the hotels' need to highlight their green/eco-friendly initiatives over these forums so customers can easily locate eco-friendly hotels.

\section{Limitation and Future Directions}

Like the majority of studies in the field of sustainability in the hospitality sector, the current study also has some limitations to report. These limitations can be taken as directions for future investigations. First, this study did not consider the ecoinitiatives taken by hotels, which might also have implications for the green behavioral intentions of hotel guests. The second limitation is related to the generalizability of the results, the scope of the survey, and the collected data, which have limited generalizability. Pakistan does share some of its characteristics with other similar emerging economies, but the environmental behavior of customers may vary significantly between these economies. Similarly, the economic and social conditions of Pakistan should be considered while interpreting the data and results of the current investigation. As a developing country with relaxed environmental regulations, it is not realistic to imagine a proactive or voluntary environmental stance by hotels from 
Pakistan. The third limitation is related to the measurement of the intentions of hotel guests rather than their actual behavior. Prior literature findings [20,31,35] support that positive behavioral intentions always result in actual behavior; however, caution is required in this interpretation as, according to Kim et al. [14], the relationship between intentions and actual behavior is not straightforward. Lastly, hotel guests from a developing country such as Pakistan might have a lower level of environmental awareness. Recent investigations $[17,18]$ on customer behavior toward environmentalism in developing countries have identified customers as inconsequential stakeholders with little to no knowledge about environmental issues.

\section{Conclusions}

With this study, we have contributed to the literature by showing the impact of value orientation on the eco-friendly attitudes of guests and how these attitudes and cognitive evaluations of hotel guests develop positive green behavioral intentions. This research's primary focus was to study the antecedents of green behavioral intentions in hotel guests. According to Merli et al. [8], environmentally friendly attitudes and demographic characteristics of hotel guests are important for a better understanding of the link between hotel green initiatives as guests' behavioral intentions. Similarly, the attitude of hotel guests can be affected by their education level, reason of stay, or whether or not they are traveling with family [75]. Moreover, most studies on green behavioral intentions have focused on a limited set of variables; however, as the phenomenon is more complex, for its better comprehension, researchers need to focus on a more holistic approach.

The current investigation identifies the factors that affect hotel guests' behavioral intentions, including their willingness to pay more and revisit intentions. To conclude, with this study, an important contribution to the literature was made by developing a holistic model, while considering moral norm-activation theory [19] and the theory of planned behavior [20], for the identification of different drivers of hotel guests' green behavioral intentions and testing the proposed model in an emerging economy context.

Funding: The APC was funded by Prince Sultan University, Riyadh, Kingdom of Saudi Arabia.

Institutional Review Board Statement: Not applicable.

Informed Consent Statement: Not applicable.

Data Availability Statement: Not applicable.

Acknowledgments: The author would like to thank Prince Sultan University, Riyadh, Kingdom of Saudi Arabia, for providing financial assistance for this study.

Conflicts of Interest: The authors declare no conflict of interest.

\section{References}

1. Kaufmann, H.R.; Mohammad, F.A.K.P.; Yianna, O. Factors affecting consumers' green purchasing behavior: An integrated conceptual framework. Amfiteatru Econ. J. 2012, 14, 50-69.

2. Papadopoulos, I.; Karagouni, G.; Trigkas, M.; Platogianni, E. Green marketing: The case of Greece in certified and sustainably managed timber products. EuroMed J. Bus. 2010, 5, 166-190. [CrossRef]

3. Chan, W.W.; Lam, J.C. Prediction of pollutant emission through electricity consumption by the hotel industry in Hong Kong. Int. J. Hosp. Manag. 2002, 21, 381-391. [CrossRef]

4. Rahman, I.; Reynolds, D. Predicting green hotel behavioral intentions using a theory of environmental commitment and sacrifice for the environment. Int. J. Hosp. Manag. 2016, 52, 107-116. [CrossRef]

5. Manaktola, K.; Vinnie, J. Exploring consumer attitude and behaviour towards green practices in the lodging industry in India. Int. J. Contemp. Hosp. Manag. 2007, 19, 364-377. [CrossRef]

6. Pizam, A. Green hotels: A fad, ploy or fact of life? Int. J. Hosp. Manag. 2009, 1, 1. [CrossRef]

7. Robinot, E.; Giannelloni, J.L. Do hotels' "green" attributes contribute to customer satisfaction? J. Serv. Mark. 2010, 24, 157-169. [CrossRef]

8. Merli, R.; Preziosi, M.; Acampora, A.; Ali, F. Why should hotels go green? Insights from guests experience in green hotels. Int. J. Hosp. Manag. 2019, 81, 169-179. [CrossRef] 
9. Kasim, A. Socio-environmentally responsible hotel business: Do tourists to Penang Island, Malaysia care? J. Hosp. Leis. Mark. 2004, 11, 5-28. [CrossRef]

10. Kim, Y.; Han, H. Intention to pay conventional-hotel prices at a green hotel-a modification of the theory of planned behavior. J. Sustain. Tour. 2010, 18, 997-1014. [CrossRef]

11. Trang, H.L.T.; Lee, J.S.; Han, H. How do green attributes elicit pro-environmental behaviors in guests? The case of green hotels in Vietnam. J. Travel Tour. Mark. 2019, 36, 14-28. [CrossRef]

12. González-Rodríguez, M.R.; Díaz-Fernández, M.C.; Font, X. Factors influencing willingness of customers of environmentally friendly hotels to pay a price premium. Int. J. Contemp. Hosp. Manag. 2020, 32, 60-80. [CrossRef]

13. Han, H.; Back, K.J. Relationships among image congruence, consumption emotions, and customer loyalty in the lodging industry. J. Hosp. Tour. Res. 2008, 32, 467-490. [CrossRef]

14. Kim, S.-H.; Lee, K.; Fairhurst, A. The review of "green" research in hospitality 2000-2014: Current trends and future research directions. Int. J. Contemp. Hosp. Manag. 2017, 29, 226-247. [CrossRef]

15. Sukawati, T.G.R.; Riana, I.G.; Rajiani, I.; Abbas, E.W. Managing corporate sustainability by revitalizing balinese cultural identity. Pol. J. Manag. Stud. 2020, 21, 382-393. [CrossRef]

16. Munro, V.; Arli, D.; Rundle-Thiele, S. CSR engagement and values in a pre-emerging and emerging country context. Int. J. Emerg. Mark. 2018, 13, 1251-1271. [CrossRef]

17. Saleem, F.; Gopinath, C.; Khattak, A.; Qureshi, S.S.; Allui, A.; Adeel, A. Corporate Environmentalism: An Emerging Economy Perspective. Sustainability 2020, 12, 6225. [CrossRef]

18. Saleem, F.; Zhang-Zhang, Y.; Malik, M.I.; Allui, A. Revisiting Stakeholder Theory and Environmentalism: Evidence from an Emerging Economy. Sustainability 2020, 12, 8751. [CrossRef]

19. Schwartz, S.H. Normative Influences on Altruism. Adv. Exp. Soc. Psychol. 1977, 10, 221-279.

20. Ajzen, I. The theory of planned behavior. Organ. Behav. Hum. Decis. Process. 1991, 50, 179-211. [CrossRef]

21. Jamali, D.; Mirshak, R. Corporate social responsibility (CSR): Theory and practice in a developing country context. J. Bus. Ethics 2007, 72, 243-262. [CrossRef]

22. Blowfield, M.; Frynas, J.G. Editorial Setting new agendas: Critical perspectives on Corporate Social Responsibility in the developing world. Int. Aff. 2005, 81, 499-513. [CrossRef]

23. Melinte, C. Analysis of environmental attitude of tourists accommodated in hotels in Bucovina area. Ecoforum J. 2020, 9, 1-8.

24. Al-Aomar, R.; Hussain, M. An assessment of green practices in a hotel supply chain: A study of UAE hotels. J. Hosp. Tour. Manag. 2017, 32, 71-81. [CrossRef]

25. Wang, L.; Wong, P.P.W.; Alagas, E.N. Antecedents of green purchase behaviour: An examination of altruism and environmental knowledge. Int. J. Cult. Tour. Hosp. Res. 2020, 14, 63-82. [CrossRef]

26. Bohdanowicz, P. European Hoteliers Environmental Attitudes. Greening the Business. Cornell Hotel Restaur. Adm. Q. 2005, 46, 188-204. [CrossRef]

27. Lewis, R.C.; Chambers, R.E. Marketing Leadership in Hospitality: Foundations and Practices, 3rd ed.; John Wiley and Sons: Hoboken, NJ, USA, 2000.

28. Han, H.; Kim, Y. An investigation of green hotel customers' decision formation: Developing an extended model of the theory of planned behavior. Int. J. Hosp. Manag. 2010, 29, 659-668. [CrossRef]

29. Kerdpitak, C. Effect of drivers pressures on green supply chain management performance within the hotel industry. Pol. J. Manag. Stud. 2019, 20, 290-299.

30. Lam, T.; Hsu, C.H. Predicting behavioral intention of choosing a travel destination. Tour. Manag. 2006, 27, 589-599. [CrossRef]

31. Han, H.; Hsu, L.T.J.; Sheu, C. Application of the theory of planned behavior to green hotel choice: Testing the effect of environmental friendly activities. Tour. Manag. 2010, 31, 325-334. [CrossRef]

32. Bamberg, S.; Schmidt, P. Theory-driven subgroup-specific evaluation of an intervention to reduce private car use. J. Appl. Soc. Psychol. 2001, 31, 1300-1329. [CrossRef]

33. Chen, M.F.; Tung, P.J. Developing an extended Theory of Planned Behavior model to predict consumers' intention to visit green hotels. Int. J. Hosp. Manag. 2014, 36, 221-230. [CrossRef]

34. Kaiser, F.G.; Scheuthle, H. Two challenges to a moral extension of the theory of planned behavior: Moral norms and just world beliefs in conservationism. Pers. Individ. Differ. 2003, 35, 1033-1048. [CrossRef]

35. Han, H.; Ryu, K. Moderating role of personal characteristics in forming restaurant customers' behavioral intentions: An upscale restaurant setting. J. Hosp. Mark. Leis. Manag. 2007, 15, 25-54. [CrossRef]

36. Han, H.; Hsu, L.T.J.; Lee, J.S.; Sheu, C. Are lodging customers ready to go green? An examination of attitudes, demographics, and eco-friendly intentions. Int. J. Hosp. Manag. 2011, 30, 345-355. [CrossRef]

37. Han, H.; Hsu, L.T.J.; Lee, J.S. Empirical investigation of the roles of attitudes toward green behaviors, overall image, gender, and age in hotel customers' eco-friendly decision-making process. Int. J. Hosp. Manag. 2009, 28, 519-528. [CrossRef]

38. Hofstede, G. Motivation, leadership, and organization: Do American theories apply abroad? Organ. Dyn. 1980, 9, 42-63. [CrossRef]

39. Triandis, H.C. Individualism \& Collectivism; Westview Press: Boulder, CO, USA, 1995.

40. Kim, Y.; Choi, S.M. Antecedents of green purchase behavior: An examination of collectivism, environmental concern, and PCE. Adv. Consum. Res. 2005, 32, 592-599. 
41. Saleem, F.; Adeel, A.; Ali, R.; Hyder, S. Intentions to adopt ecopreneurship: Moderating role of collectivism and altruism. Entrep. Sustain. Issues 2018, 6, 517-537. [CrossRef]

42. Vyas, V.; Mehta, K.; Sharma, R. Investigating socially responsible investing behaviour of Indian investors using structural equation modelling. J. Sustain. Finance Investig. 2020, 1-23. [CrossRef]

43. McCarty, J.A.; Shrum, L.J. The influence of individualism, collectivism, and locus of control on environmental beliefs and behavior. J. Public Policy Mark. 2001, 20, 93-104. [CrossRef]

44. Wang, X.; van der Werff, E.; Thijs, B.; Marie, K.H.; Linda, S. I Am vs. We Are: How Biospheric Values and Environmental Identity of Individuals and Groups Can Influence Pro-environmental Behaviour. Front. Psychol. 2021, 12. [CrossRef] [PubMed]

45. Laroche, M.; Mourali, M.; Pons, F. Individualistic orientation and consumer susceptibility to interpersonal influence. J. Serv. Mark. 2005, 19, 164-173.

46. Chen, L. A study of green purchase intention comparing with collectivistic (Chinese) and individualistic (American) consumers in Shanghai, China. Inf. Manag. Bus. Rev. 2013, 5, 342-346. [CrossRef]

47. Goh, Y.N.; Wahid, N.A. A review on green purchase behaviour trend of Malaysian consumers. Asian Soc. Sci. 2015, 11, 103. [CrossRef]

48. Kirmani, M.D.; Khan, M.N. Environmental concern to attitude towards green products: Evidences from India. Serb. J. Manag. 2016, 11, 159-179.

49. De Groot, J.I.; Steg, L. Value orientations to explain beliefs related to environmental significant behavior: How to measure egoistic, altruistic, and biospheric value orientations. Environ. Behav. 2008, 40, 330-354. [CrossRef]

50. Stern, P.C.; Dietz, T. The value basis of environmental concern. J. Soc. Issues 1994, 50, 65-84. [CrossRef]

51. Verplanken, B.; Holland, R.W. Motivated decision making: Effects of activation and self-centrality of values on choices and behavior. J. Personal. Soc. Psychol. 2002, 82, 434. [CrossRef]

52. Schultz, P.W.; Zelezny, L. Values as predictors of environmental attitudes: Evidence for consistency across 14 countries. J. Environ. Psychol. 1999, 19, 255-265. [CrossRef]

53. Guagnano, G.A. Altruism and market-like behavior: An analysis of willingness to pay for recycled paper products. Popul. Environ. 2001, 22, 425-438. [CrossRef]

54. Mas'od, A.; Chin, T.A. Determining socio-demographic, psychographic and religiosity of green hotel consumer in Malaysia. Procedia Soc. Behav. Sci. 2014, 130, 479-489. [CrossRef]

55. Teng, Y.M.; Wu, K.S.; Liu, H.H. Integrating altruism and the theory of planned behavior to predict patronage intention of a green hotel. J. Hosp. Tour. Res. 2015, 39, 299-315. [CrossRef]

56. Han, H.; Moon, H.; Lee, H. Excellence in eco-friendly performance of a green hotel product and guests' proenvironmental behavior. Soc. Behav. Personal. Int. J. 2019, 47, 1-10. [CrossRef]

57. Jaiswal, D.; Kant, R. Green purchasing behaviour: A conceptual framework and empirical investigation of Indian consumers. J. Retail. Consum. Serv. 2018, 41, 60-69. [CrossRef]

58. Yoon, H.J.; Kim, Y.J. Understanding green advertising attitude and behavioral intention: An application of the health belief model. J. Promot. Manag. 2016, 22, 49-70. [CrossRef]

59. Laroche, M.; Tomiuk, M.A.; Bergeron, J.; Barbaro-Forleo, G. Cultural differences in environmental knowledge, attitudes, and behaviours of Canadian consumers. Can. J. Adm. Sci. 2002, 19, 267-282. [CrossRef]

60. Thuy, T.T.; Hong, P.T.T. Attitude to and usage intention of high school students toward electric two-wheeled vehicles in Hanoi City. VNU J. Sci. Econ. Bus. 2019, 35, 47-62. [CrossRef]

61. Kumar, A. Exploring young adults'e-waste recycling behaviour using an extended theory of planned behaviour model: A crosscultural study. Resour. Conserv. Recycl. 2019, 141, 378-389. [CrossRef]

62. Ballantine, P.W.; Ozanne, L.K.; Bayfield, R. Why buy free? Exploring perceptions of bottled water consumption and its environmental consequences. Sustainability 2019, 11, 757. [CrossRef]

63. Lee, J.S.; Hsu, L.T.; Han, H.; Kim, Y. Understanding how consumers view green hotels: How a hotel's green image can influence behavioural intentions. J. Sustain. Tour. 2010, 18, 901-914. [CrossRef]

64. Smith, A.M.; Reynolds, N.L. Measuring cross-cultural service quality: A framework for assessment. Int. Mark. Rev. 2002, 19, 450-481. [CrossRef]

65. Baker, D.A.; Crompton, J.L. Quality, satisfaction and behavioral intentions. Ann. Tour. Res. 2000, 27, 785-804. [CrossRef]

66. Cheung, M.F.; To, W.M. An extended model of value-attitude-behavior to explain Chinese consumers' green purchase behavior. J. Retail. Consum. Serv. 2019, 50, 145-153. [CrossRef]

67. Borin, N.; Cerf, D.C.; Krishnan, R. Consumer effects of environmental impact in product labeling. J. Consum. Mark. 2011, 28, 76-86. [CrossRef]

68. Ritter, Á.M.; Borchardt, M.; Vaccaro, G.L.R.; Pereira, G.M.; Almeida, F. Motivations for promoting the consumption of green products in an emerging country: Exploring attitudes of Brazilian consumers. J. Clean. Prod. 2015, 106, 507-520. [CrossRef]

69. Cronin Jr, J.; Joseph, M.K.; Brady, G.; Tomas, M.H. Assessing the effects of quality, value, and customer satisfaction on consumer behavioral intentions in service environments. J. Retail. 2000, 76, 193-218. [CrossRef]

70. McDougall, G.H.G.; Terrence, L. Customer satisfaction with services: Putting perceived value into the equation. J. Serv. Mark. 2000, 14, 392-410. [CrossRef] 
71. Park, Y.; Njite, D. Relationship between destination image and tourists' future behavior: Observations from Jeju island, Korea. Asia Pac. J. Tour. Res. 2010, 15, 1-20. [CrossRef]

72. Yamaguchi, S. Personality and cognitive correlates of collectivism among the Japanese: Validation of collectivism scale. Unpublished Manuscript. 1990.

73. Fornell, C.; Larcker, D.F. Evaluating Structural Equation Models with Unobservable Variables and Measurement Error. J. Mark. Res. 1981, 18, 39-50. [CrossRef]

74. Joreskog, K.G.; Sorbom, D. LISREL 8: Structural Equation Modeling with the SIMPLIS Command Language; Scientific Software International: Chicago, IL, USA, 1993.

75. Luekveerawattana, R. Key factors affecting of tourists' decisions to stay at environmental friendly hotels. Pol. J. Manag. Stud. 2018, 17, 148-157. [CrossRef] 